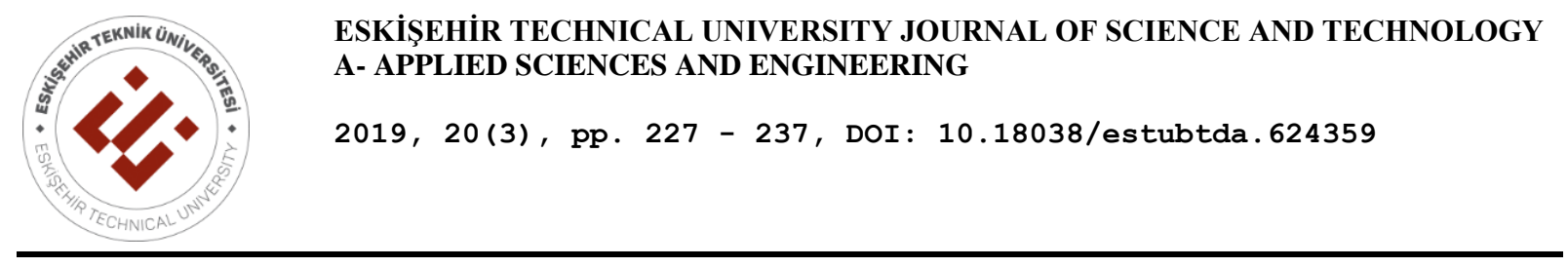

\title{
ASSESSMENT OF WIND CHARACTERISTICS AND WIND ENERGY POTENTIAL IN WEST BLACK SEA REGION OF TURKEY
}

\author{
Bayram KÖSE ${ }^{1, *}$, M. Tahir GÜNEŞER ${ }^{2}$ \\ ${ }^{1}$ Department of Energy Systems Engineering, Technology Faculty, Karabük University, Karabük, Turkey \\ ${ }^{2}$ Department of of Electrical and Electronics Engineering, Engineering Faculty, Karabük University, Karabük, Turkey
}

\begin{abstract}
In this study, wind characteristics and wind energy potential of seven cities from The West of Black Sea Region in Turkey were analyzed. The wind data were obtained by National State Meteorological Service. It was measured at 10 meters' height in the date range 2010-2014. Weibull probability density function was calculated and estimated Weibull shape parameter $k$ and scale parameter $c$, with the data for those locations. According to the power calculations of the region, annual mean power densities of Zonguldak, Bartın, Kastamonu, Bolu, Karabük, Düzce and Sinop were calculated as 105 W/m², 37,4 W/m², 40 $\mathrm{W} / \mathrm{m}^{2}, 27,15 \mathrm{~W} / \mathrm{m}^{2}, 27 \mathrm{~W} / \mathrm{m}^{2}, 26,3 \mathrm{~W} / \mathrm{m}^{2}$ and $209 \mathrm{~W} / \mathrm{m}^{2}$ at the height of $50 \mathrm{~m}$, respectively. The results show that, the region has not enough wind energy potential considering investment on wind power energy except Sinop.
\end{abstract}

Keywords: Black Sea Region wind potential, Power density, Probability distribution function

\section{INTRODUCTION}

All over the world, the scissors between energy consumption and production is pointing that current policies are not sustainable. So, a counterpoise must be found among energy consumption, generation, security, economic development and protection of the environment. In last two decades, renewable energy sources are accepted the most convenient way and most reasonable one wind energy has been growing rapidly. Developed countries have paid more attention toward wind power energy as a clean source. Most of the European countries allocated huge budgets in last decade for wind power energy. The capacities of some EU countries are 56,132 MW in Germany, 23,074 MW in Spain, 9,479 MW in Italy, 13,759 MW in France and 18872 MW in England at the end of 2017. USA reached total capacity 89,077 MW, while Canada has got installed total capacity 12,239 MW in 2017 [1-3].

Before having a decision to setup and invest, determination wind energy potential is indispensable for a proper location [3-5]. According to theoretical calculations of economic potential of wind energy in Turkey, $70 \%$ of the energy needs of the country can be supplied approximately. Turkey's economic wind potential and technical wind potential were estimated as 48,000 MW, 88,000 MW respectively. Although the installed power of Turkey is seen on Table 1 from 2002 to 2017 [3].

As the wind is affected by the stochastic structure and local geographic conditions, it is necessary to conduct feasibility and long-term measurements before the investment in the places where wind energy investment is planned. In today's world, where energy costs and energy demand are high, wind energy potential studies are continuing all over the world. A research about Canary Islands of Spain examines the wind energy potential by various analysis methods of distribution functions [6]. The wind potential of Koronos in Greece by using the measurement results obtained from observation mast. The results were statistically analyzed by using the Weibull and Rayleigh functions. Annual mean power density was calculated as $420 \mathrm{~W} / \mathrm{m}^{2}$ [7]. For the comparison of energy capacities in Germany, the market was modeled, and wind potential effect was calculated [8].

*Corresponding Author:bayramkose@ @karabuk.edu.tr

Received: 01.11.2018 Published: 26.09.2019 
Köse and Güneşer / Eskişehir Technical Univ. J. of Sci. and Tech. A-Appl. Sci. and Eng. 20 (3) - 2019

Table 1 Installed power capacity of Turkey by sources $[2,3]$.

\begin{tabular}{lrrrrrrr}
\hline Source Kind/Year & $\begin{array}{r}\mathbf{2 0 0 2} \\
(\mathbf{M W})\end{array}$ & $\begin{array}{r}\mathbf{2 0 0 9} \\
(\mathbf{M W})\end{array}$ & $\begin{array}{r}\mathbf{2 0 1 2} \\
(\mathbf{M W})\end{array}$ & $\begin{array}{r}\mathbf{2 0 1 4} \\
(\mathbf{M W})\end{array}$ & $\begin{array}{r}\mathbf{2 0 1 5} \\
(\mathbf{M W})\end{array}$ & $\begin{array}{r}\mathbf{2 0 1 7} \\
(\mathbf{M W})\end{array}$ & $\begin{array}{r}\mathbf{2 0 1 8} \\
(\mathbf{M W})\end{array}$ \\
\hline Thermal Energy & 19569 & 29339 & 35029 & 41802 & 41903 & 46926 & 46931.9 \\
Hydroelectrical Energy & 12241 & 14553 & 19620 & 23643 & 25868 & 27273 & 28336.3 \\
Wind Energy & 19 & 792 & 2261 & 3630 & 4503 & 6516 & 6995.5 \\
Geothermal Energy & 18 & 77 & 162 & 405 & 624 & 1063 & 1239.7 \\
Solar Energy & - & - & - & 40 & 249 & 3420 & 5047.4 \\
\hline Sum & 31846 & 44761 & 57071 & 69520 & 73147 & 85200 & 88550.8 \\
\hline
\end{tabular}

Various locations wind potentials were measured and evaluated in Turkey as well. In these studies, several methods can be applied such as using measurements of Turkish State Meteorological Service (TSMS) or independent measurements or estimating statistical values by using these measurements. As the measurements of TSMS, the mean power density $\left(222 \mathrm{~W} / \mathrm{m}^{2}\right)$ and average wind speed $(7,3 \mathrm{~m} / \mathrm{s})$ were determined in Gaziantep Nurdagi [9]. By using the estimating methods of Weibull and Rayleigh distributions, the potential of Elazig district was calculated via the data of the results of the measurements lasting 6 years [10-11]. In some studies, the wind power potentials of various locations to find out proper zones. Regarding the results of the measurements in the southern Anatolia, Samandag was calculated most suitable location [12]. The wind potential of the North Eastern of Turkey was observed and statistically analyzed by using the measurements of six different TSMS stations. Regarding the results, the mean wind power densities are nearly same and under $59.96 \mathrm{~W} / \mathrm{m}^{2}$, which is below than weak resource range and not feasible for investment [13].

In this study, the wind potential of the West Black Sea Region was evaluated by using real wind data obtained from TSMS. The wind speed and direction as well as the availability, the duration and the diurnal variation were assessed, and the results were statistically compared with Weibull distribution functions. Distribution function with three methods, which are Least Square Method (LSM), Maximum Likelihood Method (MLM) and Moment Method (MM) were used to determine Weibull parameters.

\section{WIND DATA AT WEST BLACK SEA REGION}

In this study, the observation values, which were taken from the weather stations of TSMS measuring at 10 meters height in Zonguldak, Bartın, Kastamonu, Bolu, Karabük, Düzce and Sinop provinces in the western black sea region, were used. The measurement data consist of hourly wind data between the years 2010-2014. Wind speed, direction, pressure, humidity and temperature values were obtained from the measurement stations which were given satellite images in Fig. 1. Descriptive statistical wind speed values of the measurement stations are seen on Table 2. Obtained wind speed values in the measurement results were extrapolated to $50 \mathrm{~m}$ via Eq.5. for energy potential calculation and the descriptive statistics of these transformed values are given on Table 3.

The wind speed data were analyzed at the measurement height. The central tendencies were calculated. Descriptive statistics were given on Table 2..The central tendency was defined as seen on Eq.(1), where $\bar{v}$ is the mean value, $v_{i}$ is the data sequence and $\mathrm{n}$ is the number of the data contained in this data sequence. The discrete degree of the data sequence relative to the mean value was obtained by the Standard deviation (Std) value as seen on Eq. (2). The distributional pattern of the data was obtained by using Skewness and Kurtosis as seen on Eq. (3) and Eq. (4) respectively [14]: 


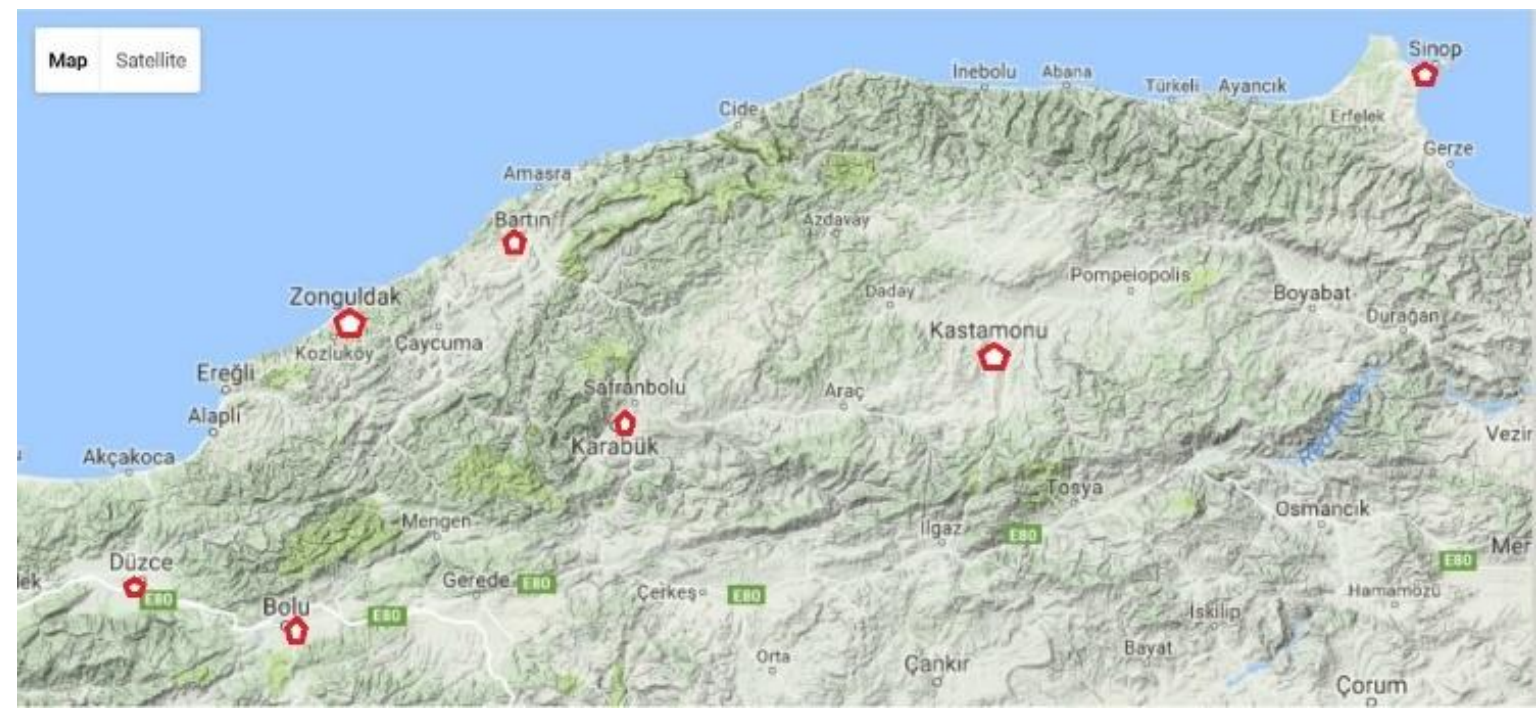

Figure 1 The locations of the weather stations

$$
\begin{gathered}
\bar{V}=\frac{1}{n} \sum_{i=1}^{n} V_{i} \\
\sigma=S t d=\sqrt{\frac{1}{n} \sum_{i=1}^{n}\left(V_{i}-\bar{V}\right)^{2}} \\
\text { Skewness }=\frac{1}{n-1} \sum_{i=1}^{n} \frac{\left(V_{i}-\bar{V}\right)^{3}}{\sigma^{3}} \\
\text { Kurtosis }=\frac{1}{n-1} \sum_{i=1}^{n} \frac{\left(V_{i}-\bar{V}\right)^{4}}{\sigma^{4}}-3
\end{gathered}
$$

Table 2. Description Statistics (10 m Observed)

\begin{tabular}{cccccccc}
\hline & Zonguldak & Bartın & Kastamonu & Bolu & Karabük & Düzce & Sinop \\
\hline Mean & 2,1900 & 2,1900 & 1,5109 & 1,3984 & 1,1475 & 1,1475 & 2,8627 \\
Std & 1,4830 & 1,4830 & 0,9122 & 0,9505 & 0,8472 & 0,8463 & 2,0083 \\
Skewness & 13,2161 & 13,2161 & 5,0283 & 4,0883 & 9,2564 & 5,0318 & 7,0559 \\
Kurtosis & 2,4220 & 2,4220 & 1,6923 & 1,6730 & 2,5252 & 1,9390 & 1,8335 \\
Max & 23,600 & 23,600 & 11,900 & 11,500 & 11,000 & 9,100 & 27,900 \\
\hline
\end{tabular}

Table 3. Description Statistics (50 m Calculated)

\begin{tabular}{cccccccc}
\hline & Zonguldak & Bartın & Kastamonu & Bolu & Karabük & Düzce & Sinop \\
\hline Mean & 2,7298 & 2,7298 & 1,8832 & 1,7431 & 1,4304 & 1,4376 & 3,5862 \\
Std & 1,8633 & 1,8633 & 1,1477 & 1,1942 & 1,0635 & 1,0602 & 2,5159 \\
Skewness & 13,041 & 13,041 & 4,9426 & 4,0437 & 9,1793 & 5,0318 & 7,0559 \\
Kurtosis & 2,3949 & 2,3949 & 1,6643 & 1,6566 & 2,5051 & 1,9390 & 1,8335 \\
Max & 29,5643 & 29,5643 & 14,9074 & 14,4063 & 13,7800 & 11,3998 & 34,951 \\
\hline
\end{tabular}


Köse and Güneşer / Eskişehir Technical Univ. J. of Sci. and Tech. A-Appl. Sci. and Eng. 20 (3) - 2019

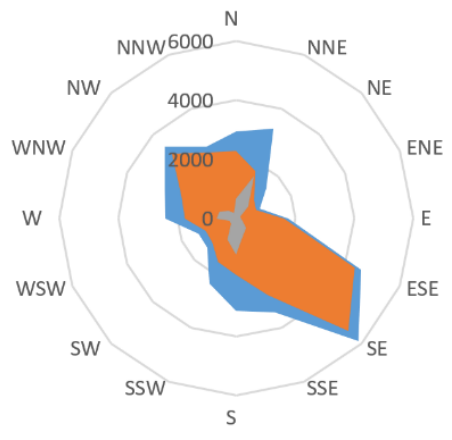

(a)

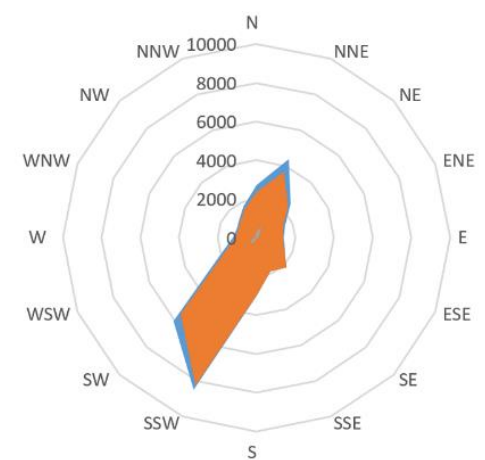

(c)

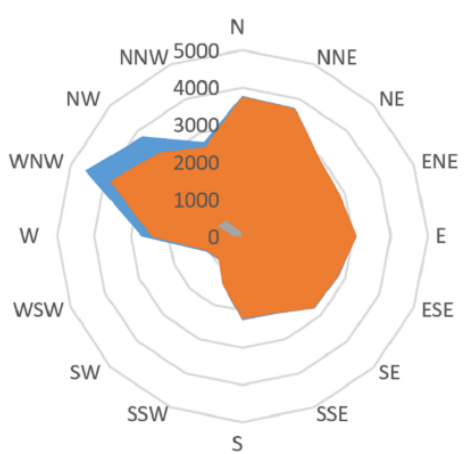

(e)

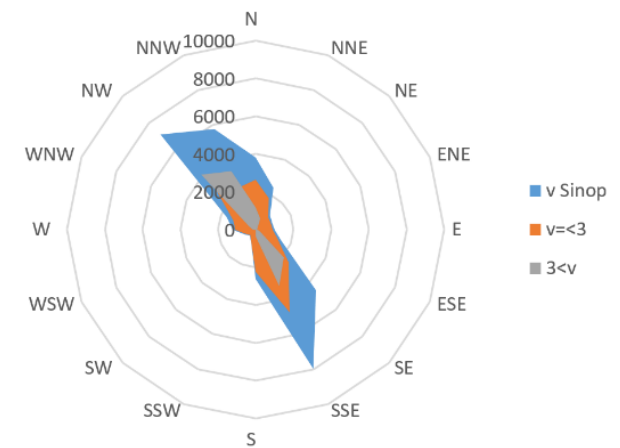

(g)

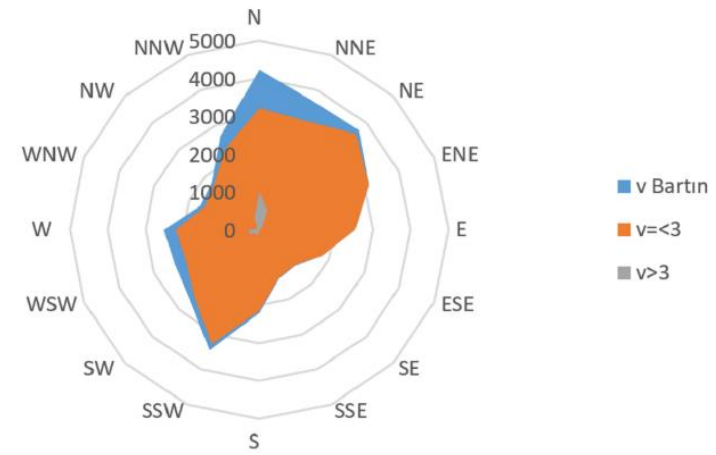

(b)

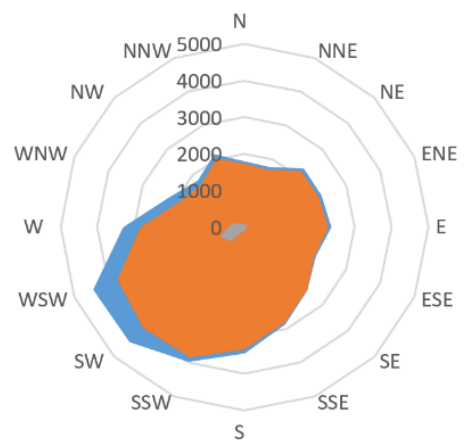

(d)

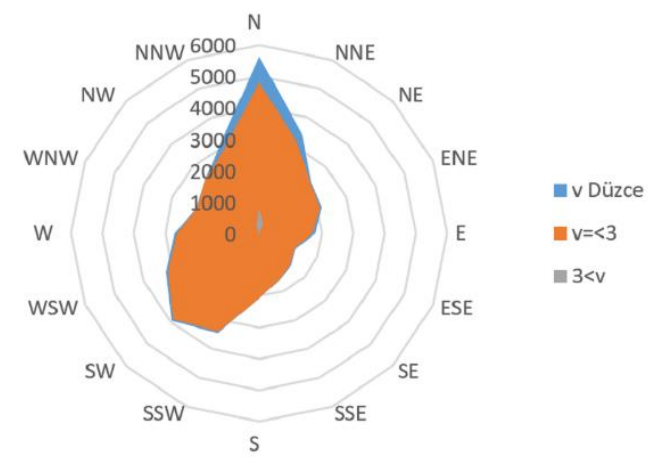

(f)

Figure 2. The wind roses of the locations are listed as: (a) Zonguldak; (b) Bartın; (c) Kastamonu; (d) Bolu; (e) Karabük; (f) Bartın; (g) Sinop 
Table 4. Description Statistics (50 m Calculated)

\begin{tabular}{cccccccc}
\hline & Zonguldak & Bartın & Kastamonu & Bolu & Karabük & Düzce & Sinop \\
\hline Mean & 2,7298 & 2,7298 & 1,8832 & 1,7431 & 1,4304 & 1,4376 & 3,5862 \\
Std & 1,8633 & 1,8633 & 1,1477 & 1,1942 & 1,0635 & 1,0602 & 2,5159 \\
Skewness & 13,041 & 13,041 & 4,9426 & 4,0437 & 9,1793 & 5,0318 & 7,0559 \\
Kurtosis & 2,3949 & 2,3949 & 1,6643 & 1,6566 & 2,5051 & 1,9390 & 1,8335 \\
Max & 29,5643 & 29,5643 & 14,9074 & 14,4063 & 13,7800 & 11,3998 & 34,951 \\
\hline
\end{tabular}

Table 5. The wind speed densities of the weather stations

\begin{tabular}{|c|l|l|l|l|l|l|l|}
\hline vr & Zonguldak & Bartn & Kastamonu & Bolu & Karabük & Düzce & Sinop \\
\hline $\mathbf{0 - 0 , 5}$ & 0,0168 & 0,1691 & 0,0467 & 0,0645 & 0,0880 & 0,1130 & 0,0167 \\
\hline $\mathbf{0 , 5 - 1 , 5}$ & 0,3415 & 0,5503 & 0,5426 & 0,5943 & 0,6995 & 0,6419 & 0,2468 \\
\hline $\mathbf{1 , 5 - 2 , 5}$ & 0,3307 & 0,1539 & 0,2816 & 0,2082 & 0,1407 & 0,1437 & 0,2386 \\
\hline $\mathbf{2 . 5 - 3 . 5}$ & 0,1570 & 0,0742 & 0,0857 & 0,0882 & 0,0402 & 0,0543 & 0,1811 \\
\hline $\mathbf{3 . 5}-\mathbf{4 . 5}$ & 0,0809 & 0,0337 & 0,0300 & 0,0330 & 0,0199 & 0,0214 & 0,1273 \\
\hline $\mathbf{4 . 5 - 5 . 5}$ & 0,0374 & 0,0122 & 0,0096 & 0,0090 & 0,0084 & 0,0050 & 0,0792 \\
\hline $\mathbf{5 . 5 - 6 . 5}$ & 0,0181 & 0,0043 & 0,0026 & 0,0019 & 0,0026 & 0,0013 & 0,0451 \\
\hline $\mathbf{6 . 5 - 7 . 5}$ & 0,0084 & 0,0014 & 0,0009 & 0,0005 & 0,0003 & 0,0002 & 0,0225 \\
\hline $\mathbf{7 . 5 - 8 . 5}$ & 0,0039 & 0,0006 & 0,0002 & 0,0003 & 0,0003 & 0,0000 & 0,0114 \\
\hline $\mathbf{8 . 5 - 9 . 5}$ & 0,0021 & 0,0002 & 0,0000 & 0,0001 & 0,0001 & 0,0000 & 0,0062 \\
\hline $\mathbf{9 . 5 - 1 0 . 5}$ & 0,0012 & 0,0000 & 0,0000 & 0,0001 & 0,0000 & 0,0000 & 0,0043 \\
\hline $\mathbf{1 0 . 5 - 1 1 . 5}$ & 0,0007 & 0,0001 & 0,0000 & 0,0000 & 0,0000 & 0,0000 & 0,0026 \\
\hline $\mathbf{1 1 . 5 - 1 2 . 5}$ & 0,0004 & 0,0000 & 0,0000 & 0,0000 & 0,0000 & 0,0000 & 0,0015 \\
\hline $\mathbf{1 2 . 5 - 1 3 . 5}$ & 0,0002 & 0,0000 & 0,0000 & 0,0000 & 0,0000 & 0,0000 & 0,0012 \\
\hline $\mathbf{1 3 . 5 - 1 4 . 5}$ & 0,0001 & 0,0000 & 0,0000 & 0,0000 & 0,0000 & 0,0000 & 0,0006 \\
\hline $\mathbf{1 4 . 5 - 1 5 . 5}$ & 0,0001 & 0,0000 & 0,0000 & 0,0000 & 0,0000 & 0,0000 & 0,0003 \\
\hline $\mathbf{1 5 . 5 - 1 6 . 5}$ & 0,0000 & 0,0000 & 0,0000 & 0,0000 & 0,0000 & 0,0000 & 0,0002 \\
\hline $\mathbf{1 6 . 5 - 1 7 . 5}$ & 0,0001 & 0,0000 & 0,0000 & 0,0000 & 0,0000 & 0,0000 & 0,0001 \\
\hline $\mathbf{1 7 . 5 - 1 8 . 5}$ & 0,0001 & 0,0000 & 0,0000 & 0,0000 & 0,0000 & 0,0000 & 0,0001 \\
\hline $\mathbf{1 8 . 5 - 1 9 . 5}$ & 0,0000 & 0,0000 & 0,0000 & 0,0000 & 0,0000 & 0,0000 & 0,0002 \\
\hline $\mathbf{1 9 . 5 - 2 0 . 5}$ & 0,0000 & 0,0000 & 0,0000 & 0,0000 & 0,0000 & 0,0000 & 0,0000 \\
\hline
\end{tabular}

\section{WIND CHARECTERISTIC AND PROBABILTY MODELS}

\subsection{Variation of Wind Speed with Height}

Generally, the wind speed measurements have been made at $10 \mathrm{~m}$ height. The wind data used in this study is extrapolated $50 \mathrm{~m}$ height above ground level. It is known that the wind speed is proportional to height. Extrapolation of the wind speed was made by Eq. (5), where $V_{o}$ and $V$ are the wind speeds at the standard height $10 \mathrm{~m}$ and at the hub height $\mathrm{h} \mathrm{m}$, respectively, and a is the roughness factor. The theoretical variation of the wind speed depending on the height varies between 0.08 and 0.4 . In this study, we took the measurement sites as 0.14 by accepting open ridges and open land cover [5].

$$
\frac{V}{V_{o}}=\left(\frac{h}{h_{0}}\right)^{\alpha}
$$

By substituting $\mathrm{h}=50$ and the measured wind speed data at the standard height $10 \mathrm{~m}$ to Eq. (5), wind speed values at the hub height are obtained. 


\subsection{Probability Models}

Weibull probability distribution function (pdf) is as follows [15];

$$
f(V)=\frac{k}{c}\left(\frac{V}{c}\right)^{k-1} \exp \left(-\left(\frac{V}{c}\right)^{k}\right),(k>0, c>0, V>0)
$$

The cumulative distribution function (cdf) of two parameter weibull distribution is as follows [15]

$$
F(V)=1-\exp \left[-\left(\frac{V}{c}\right)^{k}\right]
$$

In this formula (7); $k$ represents shape parameter, $c$ represents the scale parameter $(\mathrm{m} / \mathrm{s})$ and $V$ is observed wind speed data $[6,14]$.

\subsubsection{Least square method (LSM)}

Weibull distribution parameter is found with least square method by Eq. (8) and Eq. (9), [15,16],

$$
\begin{gathered}
y_{i}=\left[\ln \left(-\ln \left(1-F\left(v_{i}\right)\right)\right)\right] \\
k=\frac{n \sum_{i=1}^{n}\left(\ln v_{i}\right) y_{i}-\sum_{i=1}^{n} \ln v_{i} \sum_{i=1}^{n} y_{i}}{n \sum_{i=1}^{n} \ln \left(v_{i}{ }^{2}\right)-\left[\sum_{i=1}^{n} \ln v_{i}\right]^{2}} \\
c=\exp \left[\frac{k \sum_{i=1}^{n} \ln v_{i}-\sum_{i=1}^{n} \ln \left(-\ln \left(1-F\left(v_{i}\right)\right)\right)}{n \cdot k}\right]
\end{gathered}
$$

\subsubsection{Maximum likelihood method (MLM)}

With maximum likelihood method, standard iterative techniques or Newton Raphson method or trialerror techniques can be used. After numerical solution of the found as follows [6].

$$
\begin{gathered}
\frac{\sum_{i=1}^{n} v_{i}{ }^{k} \ln v_{i}}{\sum_{i=1}^{n} v_{i}{ }^{k}}-\frac{\sum_{i=1}^{n} \ln v_{i}}{n}-\frac{1}{k}=0 \\
c=\left(\frac{\sum_{i=1}^{n} v_{i}^{k}}{n}\right)^{\frac{1}{k}}
\end{gathered}
$$

\subsubsection{Moment method (MM)}

In this paper, also with Moment method, $\mathrm{k}$ and c parameters are obtained using Eq. (11) and Eq. (12) respectively, using average wind speed $(\bar{v})$ and standard deviation $(\sigma)$ of observed wind speed [3].

$$
k=\left(\frac{\sigma}{\bar{v}}\right)^{-1,086}
$$

The $\mathrm{c}$ scale parameter was calculated by Eq. (12) using the mean velocity $(\bar{v})$, the gamma function $\Gamma(\mathrm{)}$ and the k computed in Eq. (11).

$$
c=\frac{\bar{v}}{\Gamma\left(1+\frac{1}{k}\right)}
$$

The wind speed distributions measured for each province are given in Figure 3 with the wind speed density graphs obtained by Weibull probability distribution function for different parameter estimation methods with histograms graphs and the calculated distribution parameters are given in Table $7 .$. 


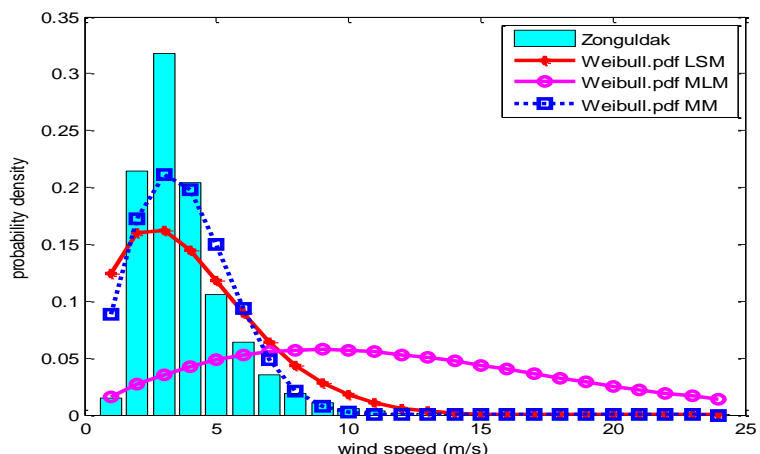

(a)

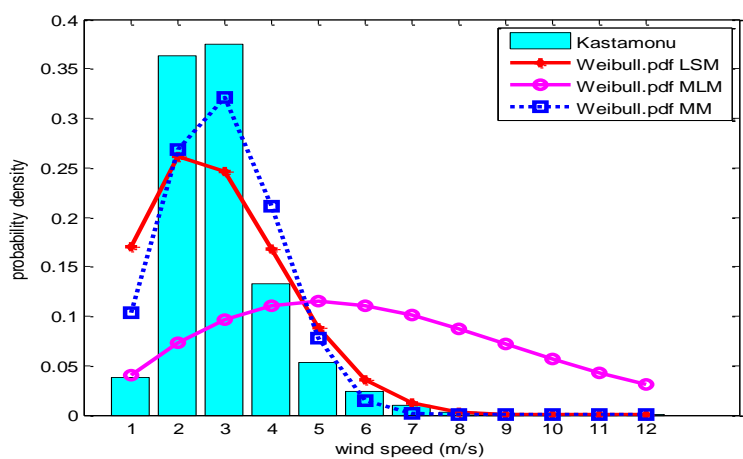

(c)

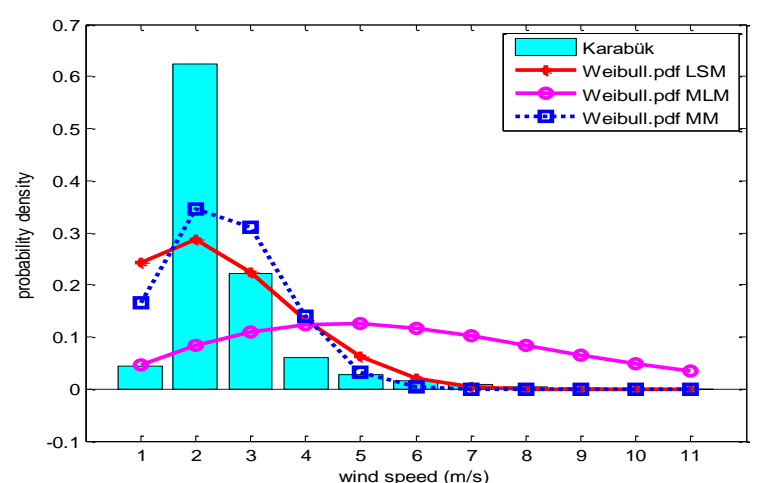

(e)

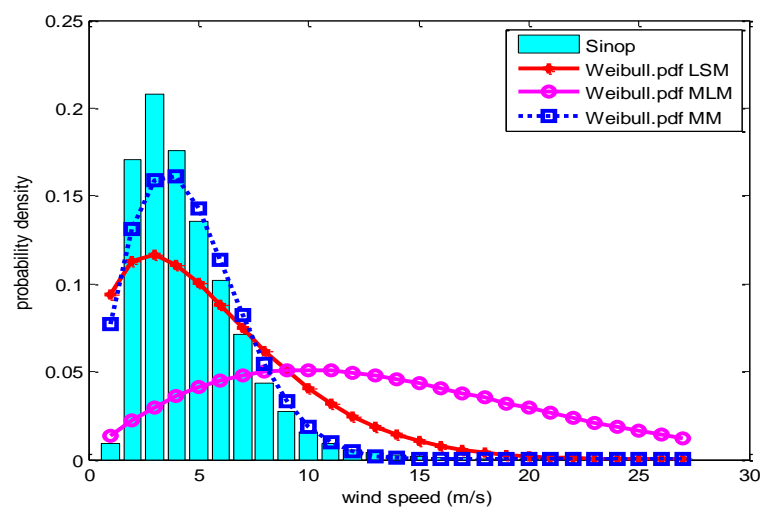

(g)

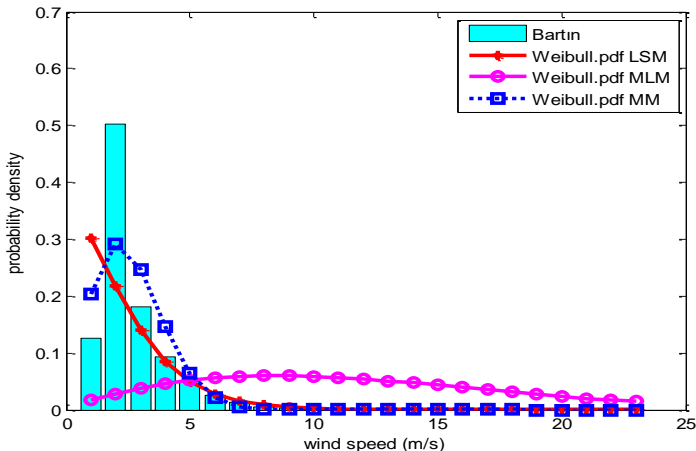

(b)

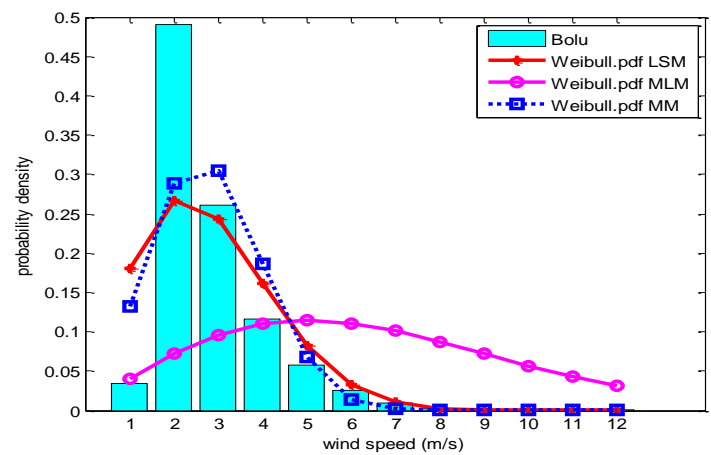

(d)

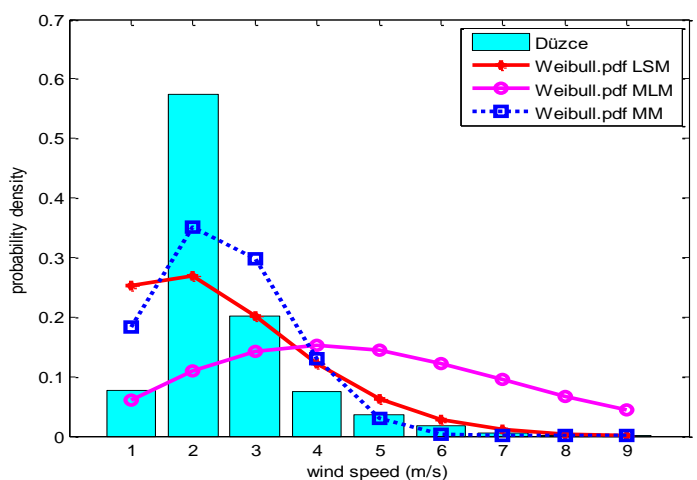

(f)

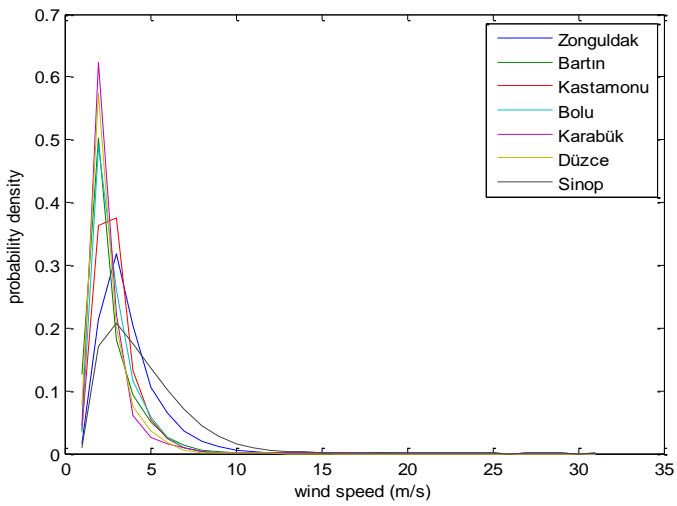

(h)

Figure 3. The wind speed densities observed and obtained from Weibulls are listed as: (a) Zonguldak; (b) Bartın; (c) Kastamonu; (d) Bolu; (e) Karabuk; (f) Bartın; (g) Sinop (h) All stations wind speed density observed. 
Köse and Güneşer / Eskişehir Technical Univ. J. of Sci. and Tech. A-Appl. Sci. and Eng. 20 (3) - 2019

Table 6 Estimating Weibull parameters for weather stations

\begin{tabular}{ccccc}
\hline & Parameters & LSM & MLM & MM \\
\hline Zonguldak & $\mathrm{k}$ & 1,6461 & 1,7995 & 2,1787 \\
& $\mathrm{c}$ & 4,6389 & 1,3419 & 4,2694 \\
\hline Bartın & $\mathrm{k}$ & 1,2051 & 1,7995 & 2,0107 \\
& $\mathrm{c}$ & 2,3503 & 13,4190 & 2,9513 \\
\hline Kastamonu & $\mathrm{k}$ & 2,0286 & 1,9314 & 2,6969 \\
& $\mathrm{c}$ & 3,2415 & 7,3100 & 3,3044 \\
\hline Bolu & $\mathrm{k}$ & 1,9937 & 1,9314 & 2,5089 \\
& $\mathrm{c}$ & 3,1689 & 7,3100 & 3,1667 \\
\hline Karabük & $\mathrm{k}$ & 1,8225 & 1,9554 & 2,5512 \\
& $\mathrm{c}$ & 2,7847 & 6,7529 & 2,8407 \\
\hline Düzce & $\mathrm{k}$ & 1,6594 & 2,0187 & 2,4701 \\
& $\mathrm{c}$ & 2,7863 & 5,6372 & 2,7777 \\
\hline Sinop & $\mathrm{k}$ & 1,4379 & 1,7768 & 1,9432 \\
& $\mathrm{c}$ & 6,3370 & 15,6358 & 5,1611 \\
\hline
\end{tabular}

\section{EVALUATION CRITERIA}

Root Mean Square Summations of Error test (RMSE) and $R$ squared $\left(R^{2}\right)$ were used to evaluate the performance of the Weibull distribution and parameter estimating methods. The RMSE parameter gives the deviation between the predicted and the measurement values. The RMSE value must be as converge to zero as possible, and its equation follow as:

$$
R M S E=\sqrt{\frac{1}{n} \sum_{i=1}^{n}\left(V_{c i}-V_{o i}\right)^{2}}
$$

Table 7. Performance of Weibull models with actual wind speed density

\begin{tabular}{lcccc}
\hline Model Performance & Criteria & LSM & MLM & MM \\
\hline Zonguldak & $R M S E$ & $\mathbf{0 . 0 4 3 7}$ & $\mathbf{0 . 0 8 5 2}$ & $\mathbf{0 . 0 3 0 6}$ \\
& $R^{2}$ & $\mathbf{0 . 9 5 4 9}$ & $\mathbf{0 . 9 5 9}$ & $\mathbf{0 . 9 5 6 1}$ \\
\hline Bartın & $R M S E$ & 0.0702 & 0.1125 & 0.0503 \\
& $R^{2}$ & 0.8539 & 0.9274 & 0.8663 \\
\hline Kastamonu & $R M S E$ & 0.0626 & 0.1291 & 0.0439 \\
& $R^{2}$ & 0.8722 & 0.8652 & 0.8895 \\
\hline Bolu & $R M S E$ & 0.0788 & 0.1411 & 0.0691 \\
& $R^{2}$ & 0.8412 & 0.8558 & 0.8322 \\
\hline Karabük & $R M S E$ & $\mathbf{0 . 1 2 1 4}$ & $\mathbf{0 . 1 7 8 9}$ & $\mathbf{0 . 0 9 8 0}$ \\
& $R^{2}$ & $\mathbf{0 . 7 1 7 1}$ & $\mathbf{0 . 7 8 4 0}$ & $\mathbf{0 . 7 0 7 7}$ \\
\hline Düzce & $R M S E$ & 0.1188 & 0.1705 & 0.0900 \\
& $R^{2}$ & 0.7695 & 0.7738 & 0.7592 \\
\hline Sinop & $R M S E$ & $\mathbf{0 . 0 3 1 9}$ & $\mathbf{0 . 0 6 2 5}$ & $\mathbf{0 . 0 1 8 5}$ \\
& $R^{2}$ & $\mathbf{0 . 9 8 3 1}$ & $\mathbf{0 . 9 7 9 4}$ & $\mathbf{0 . 9 8 4 0}$ \\
\hline
\end{tabular}

Modelling Efficiency (EF) or called $R^{2}$ represents the ability of the model. Determination Coefficient $\left(R^{2}\right)$ value is aimed to be as close as 1.0 to fit the regression line and the data well. $R^{2}$ can be calculated via Eq. (15) [19]:

$$
R^{2}=1-\frac{\sum_{i=1}^{n}\left(V_{c i}-V_{i}\right)^{2}}{\sum_{i=1}^{n}\left(V_{c i}-\bar{V}_{o}\right)^{2}}
$$

$V i$ is the ith experimental data, $\overline{V o}$ is the mean value of the experimental data, $V c i$ is the ith predicted 
data with the Weibull distribution and $n$ is the number of measurements.

For each province, Table 7 shows the measured wind speed distribution frequencies and the wind speed density values obtained by the Weibull probability distribution function for different parameter estimation methods according to the performance criteria $\left(R M S E\right.$ and $\left.R^{2}\right)$.

\section{ASSESSMENT OF WIND POWER POTENTIAL}

The power in the wind passing through an area $A$ perpendicular to the wind is given by

$$
P_{w}=\frac{1}{2} \rho A V^{3}(W)
$$

The average wind power is then

$$
\overline{P_{w}}=\frac{1}{2} \rho A \sum_{i=1}^{n} p\left(V_{i}\right) V_{i}^{3}(W)
$$

The probabilities $p\left(V_{i}\right)$ are determined from the actual wind data. If it is modelled the actual wind data by a probability density function $f\left(V_{i}\right)$, the average power is in wind is as follows [18].

$$
P_{w}=\frac{1}{2} \rho A \int_{0}^{\infty} V^{3} f(V) d V \quad(W)
$$

The average power can be shown Eq. (19), where; $\rho$ air density, $\mathrm{A}$ is an area wind passing through, $\mathrm{k}$ is shape parameter of the Weibull distribution function $f(V)$ and $\Gamma()$ is gamma function [17-19].

$$
P_{w}=\frac{1}{2} \frac{\rho A V^{3} \Gamma\left(1+\frac{3}{k}\right)}{\left[\Gamma\left(1+\frac{1}{k}\right)\right]^{3}}(W)
$$

So, for per unit area wind power density can be express,

$$
\frac{\overline{P_{w}}}{A}=\frac{1}{2} \rho \int_{0}^{\infty} V^{3} f(V) d V \quad\left(W / m^{2}\right)
$$

\begin{tabular}{|c|c|c|c|c|}
\hline Power Density $\left(\mathrm{W} / \mathrm{m}^{2}\right)$ & Actual & LSM & MLM & MM \\
\hline Zonguldak & 105,1000 & 170,6000 & 2177,7000 & 95,2000 \\
\hline Bartın & 37,4000 & 42,7000 & 2177,7000 & 34,0000 \\
\hline Kastamonu & 40,0038 & 44,6150 & 347,6355 & 37,9872 \\
\hline Bolu & 37,1514 & 42,4440 & 34,7636 & 34,9069 \\
\hline Karabük & 27,2100 & 29,3800 & 27352,0000 & 24,9300 \\
\hline Düzce & 26,3025 & 46,8968 & 273,5172 & 23,9165 \\
\hline Sinop & 209,7000 & 545,0000 & 3453,3000 & 188,6000 \\
\hline
\end{tabular}

For each province, the calculated actual mean wind power density and the Weibull probability distribution function power density results for different parameter estimation methods are given in Table 8 .

Table 8 Actual power density and obtain with Weibull and for weather stations 


\section{CONCLUSION}

In this study, yearly wind speed distribution and wind power density during the period of 2010-2014 in the seven stations of West Black Sea Region in Turkey were evaluated. It can be concluded as follows.

- The maximum value of hourly mean wind speed is determined as $2.86 \mathrm{~m} / \mathrm{s}$ at Sinop in five years period and a minimum value of $1,14 \mathrm{~m} / \mathrm{s}$ is occurred at Karabük in the same period. A maximum value of hourly mean wind speed is obtained at Sinop as $27,9 \mathrm{~m} / \mathrm{s}$.

- The mean annual value of Weibull shape parameter $\mathrm{k}$ is between 1.2051 and 2.5512 while the annual value of scale parameter $\mathrm{c}$ is between 1,3419 and $15,6318 \mathrm{~m} / \mathrm{s}$.

- The most windward directions at Bartın and Düzce are north and southwest, while the direction at Zonguldak and Sinop are southeast, Kastamonu are SSW and NNE, Bolu is SW and Karabük is WNW.

- The yearly mean wind power densities for Zonguldak, Bartın, Kastamonu, Bolu, Karabük, Düzce and Sinop are calculated to be $105 \mathrm{~W} / \mathrm{m}^{2}, 37,4 \mathrm{~W} / \mathrm{m}^{2}, 40 \mathrm{~W} / \mathrm{m}^{2}, 37,15 \mathrm{~W} / \mathrm{m}^{2}, 27 \mathrm{~W} / \mathrm{m}^{2} 26,3 \mathrm{~W} / \mathrm{m}^{2}$ and $209 \mathrm{~W} / \mathrm{m}^{2}$ at the height of $50 \mathrm{~m}$, respectively.

- The current study is an investigation study in order to estimate wind energy potential of the seven locations of the West Black Sea Region in Turkey. These locations investigated in this study can be evaluated.

\section{REFERENCES}

[1] Global Wind 2015 Report, [Online] : 31.10.2018. http://www.gwec.net/publications/global-windreport-2/global-wind-report-2015-annual-market-update/.

[2] T.C. Enerji Bakanlığı, Strateji Geliştirme Daire Başkanlığı. Dünya ve Türkiye Enerji Kaynakları Görünümü; 3: 26., [Online]: 09.09.2016. http://www.enerji.gov.tr/tr-TR/Enerji-ve-Tabii-Kaynaklar-Gorunumleri.

[3] Köse B. Ruzgar Hiz ve Potansiyelinin Stokastik Sureclerle Modellenerek Karabuk Ilinde Uygulanmasi, Doktora Tezi. Fen Bilimleri Enstitüsü, Karabük Üniversitesi, 2018.

[4] Köse B, Atila Ü, Güneşer MT, Recebli Z. An Approach to Estimate Hourly \& Daily Mean Wind Speed and Comparison with Artificial Neural Network. In: $10^{\text {th }}$ International Clean Energy Symposium, 24-26 October 2016; İstanbul.

[5] Gökçek M, Bayülken A, Bekdemir Ş. Investigation of wind characteristics and wind energy potential in Kirklareli, Turkey, Renewable Energy 2007; 32:1739-1752.

[6] Carta JA, Ramirez P, Velazquez S. A review of wind speed probability distributions used in wind energy analysis: Case studies in the Canary Islands. Renewable and Sustainable Energy Reviews 2009; 13(5): 933-955.

[7] Fyrippis AI, Axaopoulos PJ, Panayiotou G. Wind energy potential assessment in Naxos IslandGreece. Appl Energy 2010; 87(2): 577-586.

[8] Weigt, H. Germany's wind energy: the potential for fossil capacity replacement and cost saving. Applied Energy 2009; 86: 1857-1863, doi: 10.1016/j.apenergy.2008.11.031.

[9] Karsli V, Geçit C. An investigation on wind power potential of Nurdağ1-Gaziantep, Turkey, Renewable Energy 2003; 28: 823-830. 
[10] Akpinar EK, Akpınar S. Determination of the Wind Energy Potential for Maden Elazig, Turkey. Energy Conversation and Management 2004; 45: 2901-2914.

[11] Akpinar E, Kavak A. Statistical investigation of wind energy potential. Energy Sourc, Part A: Recov Utilization Environ Effects 2006; 28(9): 807-820.

[12] Sahin B, Bilgili M, Akilli H. The wind power potential of the eastern Mediterranean region of Turkey. J Wind Eng Ind Aerodynam 2005; 93: 171-183.

[13] Akpinar A. Evaluation of Wind Energy Potentiality at Coastal Locations along the North Eastern Coasts of Turkey. Energy 2013; 50: 395-405. doi: 10.1016/j.energy.2012.11.019.

[14] Wu J, Wang J, Chi D. Wind energy potential assessment for the site of Inner Mongolia in China. Renewable and Sustainable Energy Reviews 2013; 21: 215-228.

[15] Köse B, Düz M, Güneşer MT, Recebli, Z. Estimating Wind Energy Potential with Predicting Burr Lsm Parameters: A Different Approach. Sigma J Eng \& Nat Sci 2018; 36 (2): 387-402.

[16] Köse B, Küçük AZ, Ordu B, Çay Y. An overview of the probability distribution functions for forecasting of wind energy potential and Karabük wind data application. Anadolu University Journal of Science and Technology, An Applied Sciences and Engineering 2013; 3: 1-15.

[17] Akdağ SA, Dinler A. A new method to estimate weibull parameters for wind energy applications. Energy Conversion and Management 2009; 50(7): 1761-1766.

[18] Alamdari P, Nematollahi O, Mirhosseini M. Assessment of wind energy in Iran: A review. Renewable and Sustainable Energy Reviews 2012; 16 (1): 836-860.

[19] Usta I, Kantar YM. Analysis of some flexible families of distributions for estimation of wind speed distributions. Applied Energy 2012; 89: 355-367. 